\title{
MEDIA DAN PENCITRAAN PEREMPUAN
}

\author{
Nurdin Abd Halim \\ Fakultas Ilmu Komunikasi Universitas Muhammadiyah Riau \\ nurdinhalim@g.mail.com
}

\begin{abstract}
This article discusses how is the woman image in mass media and what alternative can be done to make the woman image becomes good.Of analysis can be concluded that the mass media develops the image of woman through the streotype of woman. As a result, woman always becomes the source of media commercialisation and the news concerning woman tends to be discriminative. At the online media, woman is the active consumer in comparison with man so that woman can exposed her social activity. The gender mainstreaming and woman national commission's program represents strategic resolving alternative to less the discrimination to woman in mass media. So that, to be its execution can be measured and succeed to reach the target, the activity shall be controlled by the independent institution and the government.
\end{abstract}

Kata Kunci: media, pencitraan, perempuan

\section{PENDAHULUAN}

Perjuangan para pendiri negeri ini sungguh sangat arif dan mulia dalam menyusun UUD 1945, menghargai peranan perempuan pada masa silam dan mampu mengantisipasi masa yang akan datang, dengan tidak ada satu kata pun yang bersifat diskriminatif terhadap perempuan. Bahkan pembukaan UUD 1945 dengan tegas mengatakan tentang persamaan hak dan kewajiban bagi setiap warga negara tanpa adanya diskriminatif antara satu golongan dengan golongan yang lain, perempuan dan laki-laki semua diperlakukan sama, pelaksanaannya menjadi terukur dan berhasil mencapai sasaran. 
Gambaran persamaan hak yang tertuang dalam UUD 1945 belum teraplikasi dengan baik, selalu saja muncul diskriminatif terhadap perempuan. Pada hal perempuan mempunyai peran yang sangat penting dalam sejarah kehidupan ummat manusia. Namun demikian, pandangan masyarakat terhadap kedudukan perempuan selalu mengalami pencitraan yang berbeda, sesuai dengan budaya dan ideologi masyarakat.

Pencitraan merupakan sesuatu yang sangat diperlukan oleh seseorang yang hidup di abad teknologi media karena pencitraan dapat membuat orang terkenal dan mendapatkan tempat terhormat dan memungkinkan seseorang untuk mencapai tingkatan tertentu sesuai dengan tujuan dan harapan hidup mereka. Media adalah sarana atau alat yang paling tepat pada masa sekarang untuk menciptakan pencitraan seseorang, Burhan Bungin mengemukakan bahwa dunia pencitraan seakan menemukan medium baru yang mengantarkan pergeseran besar-besaran dari personal tulisan ke personal elektronik. ${ }^{1}$ Yang dimaksudkan oleh Burhan Bungin adalah media televisi, bahkan menurutnya televisi tidak hanya berfungsi sebagai medium teknologi, tetapi lebih dari itu televisi berfungsi sebagai medium metafora dari alam semesta. Dapat diandaikan bahwa gambaran kehidupan yang dikemukakan di televisi adalah gambaran kehidupan di dunia nyata karena memang televisi sangat berperan dalam menyampaikan kejadian dan metafora tentang alam semesta dalam waktu yang sangat singkat. Artinya berita dari berbagai belahan dunia yang sangat jauh dapat disaksikan dalam sekejap mata di hadapan kita.

David Hume 2 mengatakan bahwa semua pengetahuan didasarkan pada kesan yang diterima melalui indra manusia. Jadi indra manusia, terutama sekali mata dan telinga, mempunyai peranan yang sangat penting dalam mencitrakan seseorang dari apa yang diperoleh dari lingkungan mereka. Untuk itulah pengindraan merupakan sesuatu yang menentukan pencitraan seseorang. Dalam hal ini media sangat membantu seseorang untuk melakukan penginderaan. Dikarenakan metafora kehidupan di dunia disediakan oleh media dalam bentuk program-program acara yang tersusun dengan baik dan sistematis dan dibingkai dengan adegan dan ilustrasi yang menarik. Dan seseorang dengan mudah dapat melakukan pengindraan melalui media, yang disebut dengan pencitraan tahap kedua. Karena pencitraan tahap pertama dilakukan oleh media dari apa yang dilihat dari lingkungan kehidupan sosial. Jadi peran media adalah menjadi sangat penting, karena kalau media memaparkan kesalahan atau ketidakbenaran maka akan tercipta pengindraan yang salah dan akan berakibat kepada kesalahan pencitraan dan tentu mempengaruhi seseorang dalam melakukan konstruksi sosial. Maka sangat beralasan kalau Neil Postman, sangat keras mengkritik televisi, bahwa televisi menurutnya adalah medium yang setiap saat selalu membodohi manusia. Media televisi seakan-akan selalu membawa manusia pada dunia yang penuh dengan omong kosong, berbahaya dan tidak masuk akal ${ }^{3}$. Bahkan menurut Burhan Bungin yang dimaksud oleh Neil Postman, bahwa kekuatan televisi telah membunuh kreativitas nalar manusia yang telah berkembang lewat tulis 
baca, menjadikan manusia makhluk yang cenderung mengkonsumsi menumenu informasi dan program acara yang instant. Keadaan ini tentu akan menimbulkan kesan dalam proses pencitraan seseorang yang dipengaruhi oleh media televisi ${ }^{4}$.

Perempuan selalu mempunyai keinginan untuk dikenal dan ditampilkan dalam berbagai kesempatan, tidak terkecuali di media. Selalu saja perempuan menjadi konsumsi media atau mungkin selalu saja perempuan memanfaatkan media untuk membangun citra-citra mereka dalam menggapai suatu harapan dan keinginan. Dan yang paling penting bahwa perempuan menggunakan media adalah untuk membangun citra diri mereka. Namun demikian citra perempuan di media massa masih saja bersifat klise, pada hal kondisi ini bertentangan dengan deklarasi Beijing, Beijing Declaration and Platform for Action tahun 1995, yang menyebutkan dalam salah satu butirnya, bahwa gambaran perempuan di media massa haruslah berimbang dan tidak bersifat klise. Selain itu citra perempuan di media massa cenderung mengungkapkan hal-hal yang bersifat stereotip, dan pemberitaan media juga masih diskriminatif terhadap perempuan. Tulisan ini mendiskusikan bagaimana media khususnya televisi, surat kabar dan internet melakukan pencitraan terhadap perempuan dan alternatif apa yang dapat dilakukan agar pencitraan perempuan tidak menjadi pencitraan yang klise

\section{PEMBAHASAN}

\section{Media dan Pencitraan Perempuan}

Perempuan selalu ditampilkan di media dalam berbagai bentuk, pencitraan dan komersialisasi. Menurut Burhan Bungin bahwa perempuan ditampilkan adalah untuk mengeksploitasi keindahan perempuan, dengan mengembangkan stereotip perempuan, seperti perempuan harus tampil menawan, pandai mengurus rumah tangga, pandai memasak, terampil dan dapat menyenangkan suami, cerdas dan dapat dibawa dalam berbagai kegiatan. Pada sisi yang lain perempuan dianggap sebagai sumber pengetahuan dan moral keluarga. Berbagai stereotip ini menjadi ide dan citra tetapi sekaligus menjadi sumber eksploitasi perempuan di berbagai media, dan iklan. Menurut Burhan Bungin kebanyakan iklan di media massa menggambarkan stereotip perempuan secara bebas, sehingga dapat menjadi penindasan terhadap perempuan. Perempuan juga diharuskan tampil cantik secara fisik dan tetap awet muda bila ingin sukses, dapat mengurus rumah tangga dan anggota keluarga dengan baik, di samping itu perempuan adalah sebagai objek seksual kaum laki-laki. ${ }^{5}$

Anne Autio' menjelaskan bahwa: "All groups of people women and men, girls and boys, ethnic and religious minorities, the youth and the elderly, etc are depicted in stereotypical ways. Especially the exploitation of sexual images of men has rapidly increased in the past few years, and is currently as common as the exploitation of women."7 
Penjelasan yang dikemukakan oleh Anne Autio memberi gambaran bahwa gejala eksploitasi perempuan dalam bentuk kegiatan seksual terjadi pada berbagai media di banyak negara, meskipun yang disebutkan dalam penjelasannya hanyalah Netherlands dan negara-negara Eropa yang lain. Namun, tidak dapat dipungkiri bahwa hal yang sama juga terjadi di berbagai negara, baik di kawasan Asia Pasifik atau di Asia Tenggara. Yang terjadi hari ini tontonan kita di televisi, perempuan menjadi ajang komersialisasi. Bagian tubuh perempuan digunakan untuk menciptakan daya tarik terhadap sesuatu produkproduk komersial, karena semakin tinggi nilai ketertarikan konsumen terhadap suatu barang maka semakin tinggi pula minat konsumen untuk membeli barang. ${ }^{8}$ Dan iklan di televisi telah menciptakan pencitraan yang sangat besar, karena televisi adalah media audio-visual yang mempunyai kemampuan persuasi yang ampuh dalam menyadarkan, memberi pengetahuan, merayu dan meyakinkan konsumen.

Kasus kecantikan misalnya, pada era 60-70-an, perempuan cantik memiliki tubuh kurus, kulit hitam dan rambut berombak. Dan pada tahun 80 -an dipelopori oleh iklan, standar kecantikan perempuan berubah menjadi perempuan yang memiliki kulit halus dan lembut. Atas rayuan iklan itu, masyarakat kemudian memiliki standar baru, berubah dari standar kecantikan sebelumnya. Tahun 90-an, iklan mengkonstruksi standar baru bahwa seseorang yang cantik adalah memiliki tubuh ideal (dengan lekuk tubuh yang jelas). Sekarang kulit putih, tidak sekadar halus dan lembut, tetapi ditambah lagi dengan kulit bersinar sebagai standar kecantikan. Sehingga standar kecantikan menjadi lebih rumit dan kompleks. Jadi jelas terlihat bahwa perubahan dari standar kulit cantik tidak cukup dengan perubahan warna secara fisik (hitam atau coklat kemudian menjadi putih), tetapi dari putih biasa menjadi bersinar. Dan yang akan datang kira-kira apa lagi yang dimunculkan sebagai suatu standar kecantikan. Perubahan standarisasi ini terjadi dengan cepat karena iklan telah berhasil membentuk citra terhadap suatu produk kecantikan yang dapat menjadikan kulit putih, halus, lembut dan bersinar. Demikian pula dengan kasus model rambut, iklan shampo membombardir masyarakat khususnya perempuan dengan standar baru kecantikan rambut. Dulu pada tahun 80 -an rambut yang indah adalah rambut yang sehat dan bebas ketombe. Pada tahun 90-an standar sehat dan bebas ketombe telah usang, ditambah dengan hitam berkilau dan tidak rontok, tidak dibedakan antara rambut keribo, keriting, lurus, atau berombak. Kalau dulu bentuk rambut tidak diarahkan ke model tertentu, tahun 2000-an iklan kemudian mengarahkan kepada rambut lurus. Sehingga perempuan dan laki-laki ramai-ramai melakukan rebounding untuk meluruskan rambut. Karena mereka yang keriting atau berombak merasa bukan kelompok yang berambut cantik. Maka ramai-ramai remaja meluruskan rambut mereka yang berombak, karena iklan mengisyaratkan rambut cantik itu lurus, hitam, berkilau dan mudah diaur.

Perempuan kemudian tergiring dengan arus pencitraan program acara dan iklan yang diperankan oleh perempuan cantik yang memang kulitnya 
sudah putih, halus, lembut dan bersinar sebelum menggunakan produk yang diiklankan. Konsumen perempuan yang menonton program acara dan iklan di televisi menjadi terbius dengan bujuk rayu iklan komersil. Dengan demikian perempuan telah memperlihatkan peran yang sangat dominan dalam agenda televisi. Demikian pula dengan genre tontonan sinetron selalu menekankan pada pantagonis perempuan yang mengundang khalayak untuk memberikan dukungan. Menurut Christine Geraghty (dalam Muhammad Yamin, 1993) bahwa sinetron selalu saja mengemukakan keunggulan perempuan dalam cerita yang didasarkan pada pemahaman dan pengendalian terhadap kemampuan emosional. ${ }^{9}$

Demikian pula yang terjadi pada pemberitaan isu perempuan di media massa, belum memberikan perimbangan dengan isu lain dan belum merespon kepentingan perempuan secara utuh. Pemberitaan media massa masih mendahulukan golongan laki-laki, terutama sekali ketika membahas masalah politik, negara, militer, olah raga dan berbagai wacana publik yang lain. Sebaliknya ketika mengangkat masalah domestik, barulah menonjolkan perempuan, seperti membahas masalah rumah tangga, dapur, pengasuhan anak, kosmetika dan kecantikan. Sehingga pemberitaan terkait gender di media massa masih belum memperlihatkan kesetaraan.

Pada aspek pemberitaan di media massa yang menarik diperhatikan adalah riset media mengenai penggambaran perempuan di sejumlah media nasional yang dijalankan oleh Aliansi Jurnalis Independen (AJI) mendapati bahwa berita untuk kategori kekerasan terhadap perempuan adalah sangat dominan, sementara pemberitaan yang menjelaskan kiprah perempuan masih sangat kurang dan tidak berimbang. Bahkan peneliti AJI mendapati bahwa pemberitaan media mengenai perempuan masih ada yang melanggar kode etik jurnalistik, terutama sekali pemberitaan yang berkaitan dengan kekerasan terhadap perempuan. Bahkan perempuan selalu menjadi korban kekerasan ganda, karena ditampilkan dalam pemberitaan yang diskriminatif. Riset AJI juga menunjukkan bahwa jumlah narasumber yang diwawancarai oleh media masih lebih banyak laki-laki dari pada perempuan. Kondisi ini membuat suara perempuan terabaikan dalam berbagai isu-isu perempuan. Padahal, kata Rach Alida Bahaweres ${ }^{10}$ banyak perempuan yang bisa dijadikan narasumber agar suara golongan perempuan lebih ditampilkan secara komprehensif karena cara pandang laki-laki dan perempuan dalam menanggapi isu perempuan pasti akan berbeda. ${ }^{11}$

Hasil penelitian Netty Dyah Kurniasari menunjukkan bahwa surat kabar Kompas menyajikan gambaran politisi perempuan dengan konstruksi tertentu (bias terhadap politisi perempuan). Ideologi di luar media (patriarkhi, budaya, agama dan politik) ternyata pengaruhnya sangat dominan terhadap proses produksi teks. Artinya pemberitaan yang dilakukan oleh surat kabar Kompas masih memihak kepada kepentingan-kepentingan lain dan mengabaikan kepentingan perempuan. ${ }^{12}$ 
Pada media online, juga tergambar bahwa perempuan mempunyai tingkat penggunaan media online (maya) yang sangat aktif bahkan melebihi pengguna laki-laki pada berbagai aspek. Seperti yang tergambar pada penggunaan waktu media online antara perempuan dan laki-laki.

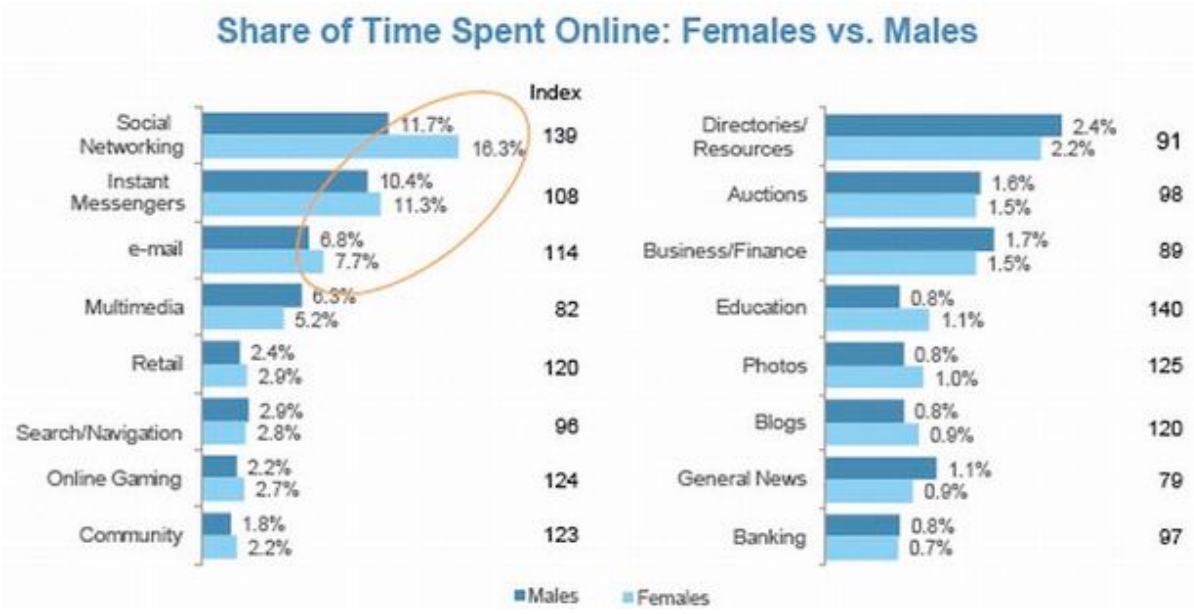

WWW.IAB.NET

Penggunaan media online untuk jejaring sosial (social networking) perempuan unggul 16,3\% berbanding laki-laki hanya 11,7\%. Begitu pula pada aspek pengiriman pesan kepada koleganya berupa kegiatan instant messengers (perempuan 11,3\% dan laki-laki 10,4\%), e-mail (perempuan 7,7\% dan laki-laki $6,8 \%$ ). Dari data tergambar bahwa perempuan mempunyai banyak waktu dan keunggulan berbanding laki-laki dalam menggunakan media online. Demikian juga dengan penggunaan fasilitas online yang lain, seperti gaming, community, education, photos, dan blogs, pengguna perempuan terlihat lebih unggul. Artinya bahwa perempuan menjadi pengguna media online yang sangat aktif dalam berbagai bentuk kegiatan. Terutama sekali kegiatan-kegiatan untuk membentuk jejaring sosial, personalitas dan publikasi-publikasi sosial yang lain.

Top Indexing Categories: \% Reach for Females vs. Males

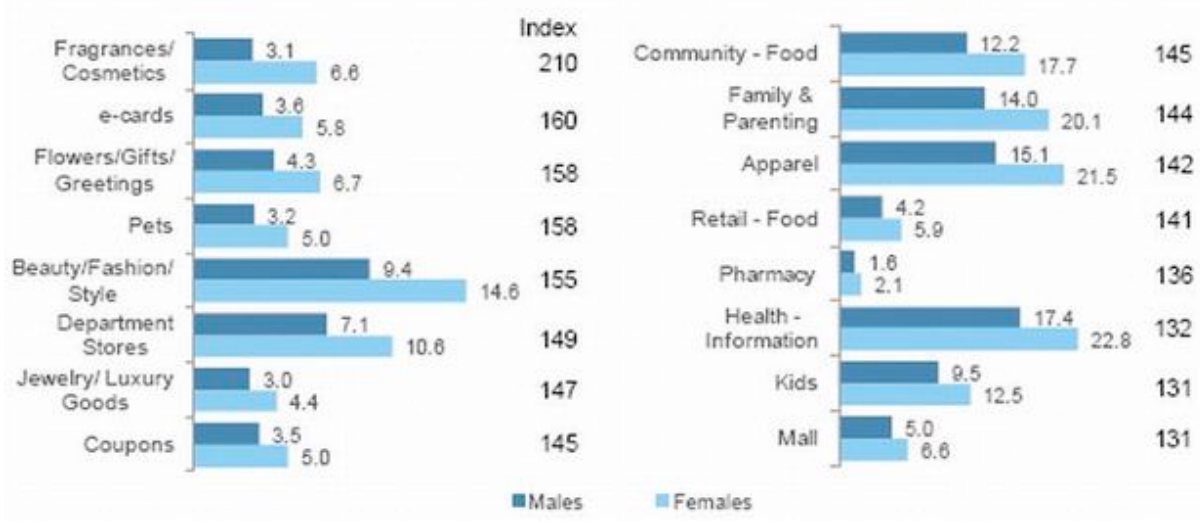

WWW.IAB.NET

Demikian halnya dengan top indek kategori-kategori penggunaan media online yang menonjol adalah perempuan dalam semua kategori, terutama sekali 
produk beauty/fashion/style (perempuan 14,6\%, laki-laki 9,4\%), department stores (perempuan 10,6\%, laki-laki 7,1\%), apparel (busana) (perempuan 21,5\%, laki-laki 15,1\%) dan health information (perempuan 22,8\%, laki-laki 17,4\%). Data top indek memberi gambaran bahwa semua indek yang dibandingkan dalam penggunaan internet, pengguna perempuan adalah lebih banyak, dan pengguna laki-laki tidak ada yang unggul pada semua kategori. Gambaran ini menunjukkan betapa perempuan memainkan peranan yang sangat penting dalam menggunakan media online terutama sekali pada kategori-kategori yang popular dalam pergaulan sosial. Sehingga dapat dikatakan bahwa tahun 2010, $46 \%$ pengguna internet di seluruh dunia adalah perempuan.

Pada kedua media, televisi dan media internet perempuan adalah pengguna media yang aktif. Bedanya bahwa pada media televisi perempuan selalu menjadi mangsa komersialisasi media, sedangkan pada media maya, justru perempuan sangat aktif menggunakan media untuk tujuan dan kegunaan tertentu. Akan tetapi kedua media sama-sama dapat digunakan untuk menciptakan pencitraan diri bagi perempuan atau sebagai alat aktualisasi diri, sehingga perempuan dengan mudah mendapat pengakuan dari publik.

Pembicaraan perempuan di media tidak akan terlepas dari pembicaraan masalah gender karena gender erat kaitannya dengan aspek budaya dan konstruksi sosial. Jane Sherron de Hart dan Linda K. Kerber dalam artikelnya yang berjudul "Gender and the New Women's History" menjelaskan bahwa "gender it self is a social construction", di mana pernyataannya menjelaskan bahwa terdapat perbedaan istilah gender dan seks. Pernyataan ini juga mendapat dukungan dari Kamla Bhasin yang mengutip Ann Oakley, penulis buku Sex, Gender and Society (1985) menjelaskan bahwa "Gender" adalah masalah budaya, ia merujuk kepada klasifikasi sosial dari laki-laki dan perempuan menjadi "maskulin" dan "feminism" kriteria yang bersifat budaya, berbeda karena waktu dan tempat. ${ }^{13}$

Pembahasan terdahulu memberi gambaran bahwa gender feminism menjadi objek dan sekaligus subjek media yang sangat produktif dalam berbagai aspek kehidupan sosial. Dan yang harus dipahami bahwa para penonton sinetron melakukan proses pemaknaan atas ikon-ikon, adegan-adegan atau alur cerita sinetron kemudian menyesuaikan dengan kerangka pikir yang mereka miliki. ${ }^{14}$ Apabila terjadi kecocokan maka sinetron itu akan terus ditonton, sebaliknya kalau alur cerita tidak bersesuaian dengan kerangka pikir, maka ia akan ditinggalkan. Karena alur cerita yang dominan ditonjolkan adalah seluk beluk kehidupan perempuan maka kebanyakan sinetron itu bersesuaian dengan kerangka pikir perempuan, dengan demikian kesesuaian ini akan mengarahkan perempuan untuk mengkonstruksi nilai-nilai yang akan menjadi realitas sosial mereka.

Muh. Labib mengutip pandangan Max Weber yang menjelaskan bahwa realitas sosial merupakan perilaku sosial yang memiliki makna subjektif, karena itu menurut Muh. Labib perilaku selalu saja memiliki tujuan dan motivasi tertentu. Prilaku memiliki kepastian terhadap suatu nilai kalau ia menunjukkan 
keseragaman dengan perilaku yang berlaku secara umum dalam masyarakat, maka akan ditiru dan dipraktekkan dalam kehidupan. Sebaliknya apabila perilaku itu bertentangan dengan norma atau nilai yang berlaku maka perilaku itu akan dikonsolidasikan dan disosialisasikan secara bertahap kemudian lambat laun menjadi norma yang berlaku secara umum bagi masyarakat. ${ }^{15}$

Sejalan dengan itu Berger dan Luckmann ${ }^{16}$, menjelaskan bahwa realitas terdiri atas realitas objektif, realitas simbolik dan realitas subjektif. Realitas objektif adalah realitas yang terbentuk dari pengalaman di dunia objektif yang berbeda di luar diri individu. Realitas simbolik adalah ekspresi simbolik dari realitas objektif dalam berbagai bentuk. Sedangkan realitas subjektif merupakan realitas yang terbentuk sebagai proses penyerapan kembali realitas objektif dan simbolik ke dalam individu melalui proses internalisasi.

Televisi dapat dilihat sebagai sarana untuk menciptakan realitas baru, atau dikenal dengan istilah second hand reality, yaitu realitas tangan kedua, atau realitas yang terbentuk dari suatu realitas yang lain, yang penuh dengan rekayasa, simbolis dan mengandung nilai dari ideologi tertentu. Dengan perkembangan teknologi televisi sehingga Simon During 17 menyatakan bahwa televisi mampu menciptakan dan merancang program acara dengan menggunakan efek suara dan ilustrasi gambar yang sempurna sehingga seolaholah tidak ada perbedaan antara realitas kehidupan sosial dengan realitas yang digambarkan oleh televisi.

Keadaan ini tentu membuat khalayak menjadi ambigu dalam menentukan sikap terhadap yang ditontonnya, sehingga menjadikan mereka sukar menentukan realitas sosial yang mana yang harus menjadi acuan dalam kehidupan mereka. Demikian halnya kehidupan perempuan akan dengan mudah merubah dan mengganti realitas sosial mereka setelah mendapatkan realitas baru dari hasil tontonan mereka di televisi.

Tania Modleski (dalam Schement, 2002:930) mendapati bahwa perempuan tertarik pada opera sabun karena perempuan mampu mengikuti cara bertutur (naratif) yang bercorak feminin ketimbang yang maskulin. Jadi opera sabun (sinetron) sengaja diciptakan dengan mengikuti cara berpikir dan berperasaan perempuan. Ia mendefinisikan narasi feminin pada opera sabun sebagai: (1) cerita bersifat nonlinear, yang berarti tidak ada kejelasan tentang permulaan, bagian tengah, dan akhir cerita, (2) didasarkan pada dialog ketimbang tindakan, (3) memuat sejumlah interupsi, dan (4) menyebarkan perhatian dan kesetiaan bagi penonton, sehingga penonton akan tetap setia mengikuti jalan cerita yang tidakjelasjalanceritanya. ${ }^{18}$

Sinetron yang disampaikan cenderung bertele-tele, dan tidak menggambarkan fenomena yang sesuai dengan fenomena masyarakat di mana khalayak berada, tetapi fenomena yang digambarkan adalah fenomena yang dibangun dengan illusi dan khayal belaka. Sinetron menampilkan episode yang terlalu besar dan tidak pernah berujung, tergantung kepada rating penonton, maka tidak jarang seseorang tidak dapat melihat semua episode yang ditawarkan karena terlalu banyak. Yang muncul adalah khalayak memberi 
kesimpulan sendiri-sendiri, sebelum sinetron memberikan kesimpulan. Demikian halnya suatu jalan cerita selalu terputus-putus karena diselingi oleh pemaparan iklan yang kadang-kadang mengalihkan perhatian penonton kepada isu-isu yang lain. Atau karena jumlah episode yang terlalu banyak sehingga penonton meninggalkan sinetron dan membuat kesimpulan sendiri-sendiri terhadap jalan cerita yang disampaikan. Maka jelas pesan yang disampaikan tidak utuh dan tidak sempurna.

Demikian besarnya permasalahan yang ditimbulkan oleh media televisi, tidak jauh bedanya dengan media surat kabar dan media online. Pada media surat kabar perempuan selalu mendapat perlakuan yang tidak berimbang sehingga menimbulkan pencitraan yang tidak menyeluruh, perempuan selalu dicitrakan menjadi kelompok kelas nomor dua yang keberadaannya hanya untuk menjadi pelengkap dan memenuhi keperluan laki-laki. Jadi yang menjadi pemilik semesta sebenarnya selalu saja laki-laki. Sedangkan pada penggunaan media interaktif online perempuan adalah sangat aktif. Artinya perempuan berupaya sedemikian rupa untuk mencitrakan dirinya dalam berbagai bentuk kegiatan media online seperti bergabung pada komunitas jejaring sosial (facebook, twiter, netlog, dan lain-lain), melakukan kegiatan bisnis, hiburan, model, konsumerisme dan kegiatan sosial yang lain. Yang jelas bahwa perempuan selalu aktif mengekspos aktivitas sosialnya pada media online.

\section{Alternatif Pemecahan}

Media massa telah membantu perempuan dalam mengkonstruksi nilai dan norma yang menjadi pegangan bagi perempuan dalam menjalankan aktivitas kehidupan mereka. Yang terpenting dari semua itu harus ada suatu upaya mencapai tujuan strategis yaitu membangun dan memberdayakan perempuan dalam kehidupan mereka setara dengan kehidupan laki-laki.

Gerakan kesetaraan yang berdenyut di ranah publik memberi tuntutan perempuan untuk lebih aktif, berpikir kritis, bekerja cepat, dan memiliki visi progresif. Selain itu, gerakan emansipasi yang memiliki gaung kencang di berbagai ranah kehidupan, hendaknya dikontekstualisasikan dalam alam faktual. Isu Feminisme hendaknya tidak hanya sebatas ide, yang mengemuka di berbagai forum diskusi, seminar, ruang kuliah, maupun perdebatan panjang di kafe-kafe dan di ruang publik yang penuh inspirasi. Emansipasi perempuan hendaknya tidak hanya membangkitkan image positif perempuan di media massa. Justru yang penting adalah gerakan strategis, praktis dan konkrit yang mementingkan kaum hawa hendaknya diupayakan sehingga kesenjangan dapat teratasi, dan tantangan terhadap krisis ekologis warga negeri ini akan dapat diselesaikan. Dan semangat UUD 1945 akan teraplikasi dengan baik.19

Suatu strategi yang perlu mendapat perhatian adalah gender mainstreaming. Strategi ini tertuang di dalam Instruksi Presiden (Inpres) No. 9 tahun 2000 tentang gender mainstreaming dalam Pembangunan Nasional. Dengan gender mainstreaming, pemerintah dapat bekerja secara lebih efisien dan efektif dalam memproduksi kebijakan-kebijakan publik yang adil dan responsif gender 
kepada seluruh lapisan masyarakat, baik pria maupun perempuan. Dengan strategi itu juga, program pembangunan yang akan dilaksanakan akan menjadi lebih sensitif atau responsif gender. Hal ini pada gilirannya akan mampu menegakkan hak-hak dan kewajiban-kewajiban pria dan perempuan atas kesempatan yang sama, pengakuan yang sama dan penghargaan yang sama di masyarakat. Di samping itu gender mainstreaming, bertujuan untuk terselenggaranya perencanaan, pelaksanaan, pemantauan dan evaluasi atas kebijakan dan program pembangunan nasional yang berperspektif gender. ${ }^{20}$

Demikian halnya dengan strategi yang dikemukakan Komnas Perempuan dalam 5 tahun ke depan yang menitikberatkan pekerjaannya pada tiga isu utama yang perlu menjadi perhatian, yaitu: 1. Meningkatnya upaya Negara Republik Indonesia untuk memenuhi tanggung jawabnya atas penegakan hak-hak asasi perempuan, dimana di dalamnya menyasar kepada: (a) adanya peraturan dan kebijakan yang mendukung pemenuhan hak-hak asasi perempuan; (b) adanya perubahan perilaku aparat negara yang lebih tanggap terhadap kebutuhan dan hak-hak perempuan; (c) adanya mekanisme pengungkapan dan penyelesaian kasus pelanggaran hak asasi perempuan; dan (d) adanya pola kerjasama yang sinergis antara lembaga-lembaga negara dalam pemenuhan hak-hak perempuan. 2. Meningkatnya peran serta masyarakat dalam pemenuhan hak-hak korban, yang di dalamya mencakup: (a) terbukanya peluang lebih besar untuk pemenuhan hak korban; dan (b) penguatan kapasitas masyarakat dalam menyikapi kekerasan terhadap perempuan. 3. Kokohnya kelembagaan Komnas Perempuan sebagai Komisi Nasional yang independen, efektif, terpercaya, dan akuntabel, yang mencakup: (a) budaya organisasi yang kuat; (b) kebijakan dan peraturan dasar yang efektif; (c) sistem manajemen SDM, administrasi, keuangan, dan SDM; (d) sistem PME yang interaktif antara program dan keuangan; dan (e) ketersediaan dana.

\section{SIMPULAN}

Perempuan dalam memenuhi kebutuhan sosialnya telah menggunakan media massa terutama untuk pencitrakan dirinya. Hal ini terbukti dari keterlibatan perempuan yang sangat dominan dalam media massa, terutama sekali televisi, surat kabar dan internet. Media-media tersebut menjadi bagian yang tidak dapat dipisahkan dari kehidupan perempuan. Untuk menguatkan pencitraan tersebut, perempuan haruslah berupaya untuk mengkonstruksi nilai sosial dan norma yang berlaku di sekitarnya. Oleh karena itu perlu strategi yang tepat untuk memanfaatkan media sebagai alat pencitraan dan konstruksi sosial, sehingga media menjadi alat yang bermakna dalam mengambil bagian memenuhi kebutuhan perempuan. Langkah strategis yang dikemukakan di atas yaitu gender mainstreaming dan program Komnas Perempuan. Langkah strategis tersebut haruslah dikontrol oleh pemerintah dan lembaga-lembaga independen sehingga pelaksanaannya menjadi terukur dan berhasil mencapai sasaran. 


\section{Endnotes:}

Burhan Bungin. 2011. Sosiologi Komunikasi. Jakarta: Kencana.

Gordon, S. 1991. The History and Philosophy of social science. London: Routledge.

Postman, N. 1985. Amusing Ourselves ot Death: Public Discourse in the Age of Business. Amerika Serikat: Viking Penguin Inc.

4 Burhan Bungin. 2011. Sosiologi Komunikasi. Jakarta: Kencana.

5 Ibid

6 (Managing Editor for the European Journalism Centre)

7 Beijing+15. Preliminary brief on the online discussion, Women and the media. http://www.un.org/womenwatch/beijing15/ 2010

8 Burhan Bungin. 2001. Imaji media massa, konstruksi dan makna realitas sosial iklan televisi dalam masyarakat kapitalistik. Yogyakarta: Jendela.

9. Muhammad Yamin. Sinetron pendisiplinan pasar dan utopia perempuan. http://www.menegpp.go.id/index.php?option=com_content\&view=article\&id=1993

10 (Koordinator Divisi Perempuan AJI Indonesia)

11 Kompas.com. AJI:Citra Perempuan di Pemberitaan Media Masih Klise http:/ / female.kompas.com/read/2011/03/09/1701011/

12 Netty Dyah Kurniasari. 2010. Gambaran Politisi Perempuan Dalam Arena PolitikbIndonesia Di Media Massa. Tesis Master. Surabaya: Fakultas Ilmu Sosial Ilmu Politik Universitas Airlangga

13 Kamla Bhasin. 2003. Memahami Gender.: Jakarta: Teplok Press.

14 Muh Labib. 2002. Potret sinetron Indonesia: antara realitas virtual dan realitas sosial. Jakarta: MU:3 Books.

15 Ibid

16 Berger, P.L. \& Luckmann, T. 1967. The social construction or reality. New York: Anchor.

17 During, S. 1994. The Cultural Studies Reader. London: Routledge.

19 Republika. Perempuan untuk kesadaran lingkungan. http://artikelmedia.blogspot.com/2010/04/

20 Wayan Sudarta. 2003. Peranan Perempuan Dalam Pembangunan Berwawasan Gender. Artikel. Jurusan Sosial Ekonomi Pertanian Fakultas Pertanian Universitas Udayana.

\section{DAFTAR PUSTAKA}

Beijing+15. Preliminary brief on the online discussion, Women and the media. http://www.un.org/womenwatch/beijing15/ 2010

Berger, P.L. \& Luckmann, T. 1967. The social construction or reality. New York: Anchor.

Burhan Bungin.2001. Imaji media massa, konstruksi dan makna realitas sosial iklan televisi dalam masyarakat kapitalistik. Yogyakarta: Jendela.

Burhan Bungin.2011. Sosiologi Komunikasi. Jakarta: Kencana.

During, S. 1994. The Cultural Studies Reader. London: Routledge.

Gordon, S. 1991. The History and Philosophy of social science. London: Routledge.

Kamla Bhasin. 2003. Memahami Gender. Jakarta: Teplok Press

Kompas.com. AJI:Citra Perempuan di Pemberitaan Media Masih Klisehttp:/ female.kompas.com/read/2011/03/09/1701011/ 
Muh Labib. 2002. Potret sinetron Indonesia: antara realitas virtual dan realitas sosial. Jakarta: MU:3 Books.

Muhammad Yamin. 1993. Sinetron pendisiplinan pasar dan utopia perempuan. http://www.menegpp.go.id/index.php?option=com_ content\&view $=$ article\&id

Netty Dyah Kurniasari. 2010. Gambaran Politisi Perempuan Dalam Arena PolitikbIndonesia Di Media Massa. Tesis Master. Surabaya: Fakultas Ilmu Sosial Ilmu Politik Universitas Airlangga.

Postman, N.1985. Amusing Ourselves ot Death: Public Discourse in the Age of Business. Amerika Serikat: Viking Penguin Inc

Republika. Perempuan untuk kesadaran lingkungan. http://artikelmedia.blogspot.com/2010/04/

Schement, Jorge Reina [ed]. 2002. Encyclopedia of Communication and Information: Volume 3.

Wayan Sudarta. 2003 Peranan Perempuan Dalam Pembangunan Berwawasan Gender. Artikel. Jurusan Sosial Ekonomi Pertanian Fakultas Pertanian Universitas Udayana.http:/ / ejournal. unud.ac.id/abstrak/peran\%20perempuan.pdf 